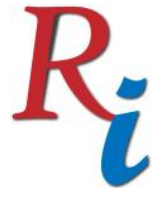

Asia Proceedings of Social Sciences

(APSS)

www.readersinsight.net/APSS

\title{
A Theoretical Framework for Supporting The Internationalization of SMEs
}

\section{Thesa Adi Purwanto*}

Tax Administration Laboratory, Universitas Indonesia Indonesia

*Corrosponding author's Email: thesa@vokasi.ui.ac.id

Peer-review under responsibility of $4^{\text {th }}$ Asia International Conference 2018 editorial board (http://www.utm.my/asia/our-team/) (C) 2018 Published by Readers Insight Publisher, lat 306 Savoy Residencia, Block 3 F11/1,44000 Islamabad. Pakistan, info@ readersinsight.net This is an open access article under the CC BY-NC-ND license (http://creativecommons.org/licenses/by-nc-nd/4.0/). 


\section{Research High Iight s}

Research on small and medium-sized enterprises (SMEs) focuses on the reasons and the way in which SMEs are moving towards internationalization. The majority uses one of the three commonly used approaches, namely the economic, the network and the organizational approach. Each provides an illustration that is consistent with his or her point of view but can not afford a comprehensive overview of SMEs internationalization. This study aims to combine these three approaches by creating a structured framework theory. In this study, the method used is the qualitative approach with the higher level of content analysis. This study is conducted by collecting and studying data and information obtained from journals, and other sources of literature.

The results depict that the rapidly evolving concept of digital technology now seems to be a unifying factor in the integration of these three approaches. This concept can provide explanations not only about the "why," but also about "how" SMEs internationalization.

\section{Graphic a I A bstract}

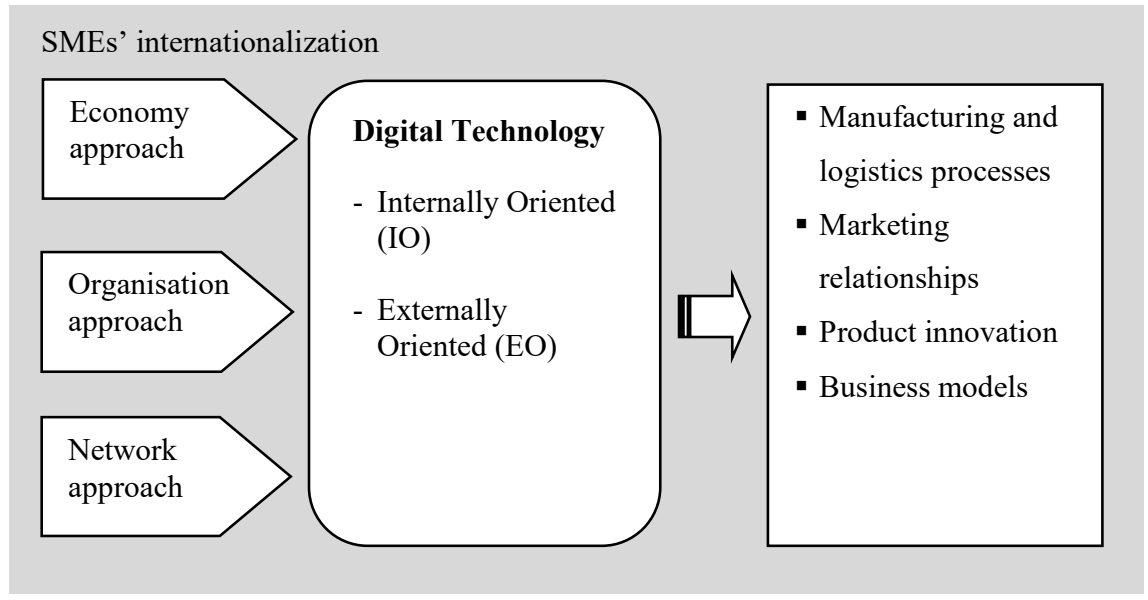




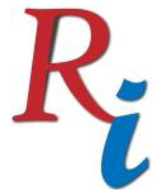

Asia Proceedings of Social Sciences

(APSS)

www.readersinsight.net/APSS

\section{Research Objectives}

Currently, research on SMEs focuses on the reasons and the way in which SMEs are moving towards internationalization (Ruzzier, Hisrich \& Atoncic, 2006). Laghzaoui (2011) attempted to propose new formulations by adding resource factors and skills to the three methods used by previous researchers. Researchers use to integrate all research contributions using these three approaches. The process of internationalization of SMEs can be adequately explained if a combination of these three approaches is used (Leonidou, Katsikeas \& Samiee, 2002). Today's most advanced digital technology, including fast and inexpensive access to information, opens up a vast opportunity for SMEs to innovate further (Redoli, et al, 2008). Rapid digitization and Internet access are the primary drivers of the SMEs strategy to address various operational issues (Noori \& Lee, 2006). In developed and developing economiesSMEs are becoming innovation-driven, with multiple applications of information technology in various fields ( $\mathrm{Wu}$, et al, 2016). The objectives are two (1) to examine the three methods to explain the process of internationalization of SMEs, and (2) to reformulate the contribution of the three existing approaches by considering aspects of the development of digital technology today.

\section{Methodology}

This research epistemology uses the interpretative paradigm to observe and solve a problem that emphasizes the socially constructed nature of reality. Guba (1990) explained that in the context of research design, the selection of the research paradigm would guide the entire research process. The research paradigms are to determine the problem addressed and an explanation of what can be accepted (Kuhn, 1970). Sarantakos (1998) believes that there are three dominant paradigms in the social sciences, the positivist, the interpretive and the critical. In this research, the approach used is the qualitative approach. Cresswell defines a qualitative study as: "a process of understanding a social or human problem based on the construction of a complex and holistic image, formed with words, reporting detailed views of informants and carried out in a natural setting" (Neuman, 2013). The type of research used is descriptive. The descriptive study can be interpreted with problem-solving procedures that are studied by describing the state of the subject or object of the study at present based on facts that appear or as they are (Soejono \& Abdurrahman, 2005). This study is conducted by collecting and studying data and information obtained from journals, and other sources of literature. 


\section{Results}

Initial research on international business development is not specifically targeted at SMEs. The weakness of the economic approach is the difficulty of applying this approach to analyze the process of internationalization of SMEs because in principle this approach is used for large companies. Therefore, the idea of using an organizational method that states that the process of internationalization is a linear and sequential process composed of several stages (Coviello and Mcauley, 1999). Because this approach involves several stepwise variations, the results of the study are subject to much criticism, mainly when used to examine the process of internationalization of small and medium-sized enterprises. Since this approach cannot fully explain the process of internationalization of small and medium enterprises (Westhead, Ucbasaran \& Biks, 2004), another approach, the network approach, is needed. Although there are already several approaches to analyzing the process of internationalization SMEs, researchers still need a common framework that can be used to explain the process of internationalization on small and medium-sized enterprises (Hutchinson, Alexander \& Quinn, 2005). With the framework should complement existing approaches and match the different characteristics of SMEs. Therefore, it can be proposed the development of digital technology as a unifying concept in an existing approach.

\section{Findings}

The rapidly evolving concept of digital technology now seems to be a unifying factor in the integration of the three approaches. This concept can provide explanations about "how" SMEs in the process of internationalization. This study contributes to understanding the process of internationalization of SMEs through the concept of digital technology. This concept combines all existing approaches to illustrate the diversity of the process of internationalization of SMEs. The results of this study have put digital technology at the heart of the analysis of SMEs The concept can capture the essential characteristics of SMEs in the development of the current era. 


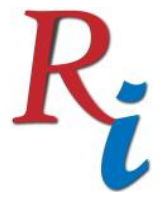

References
Asia Proceedings of Social Sciences

(APSS)

www.readersinsight.net/APSS

Ruzzier, M. R., Hisrich, D., Atoncic, B. (2006). SME internationalization research: past, present and future. Journal of Small Business Enterprise Development, 13, 476-497.

Soulaimane Laghzaoui. (2011). SMEs' internationalization: an analysis with the concept of resources and competencies. Journal of Innovation Economics \& Management, 7, 181-196.

Leonidou, L. C., Katsikeas, C. S., Samiee, S. (2002). Marketing strategy determinants of export performance: a meta-analysis. Journal of Business Research, 55, 51-67.

Redoli, J., Mompo, R., García-Díez, J., López-Coronado, M. (2008). A model for the assessment and development of Internet-based information and communication services in small and medium enterprises. Technovation 28, 7 , 424-435.

Noori, H., Lee, W.B. (2006). Dispersed network manufacturing: adapting SMEs to compete on the global scale. Journal of Manufacturing Technology Management, 17, 1022-1041.

Wu, J., Wang, C., Piperopoulos, P., Zhou, B. (2016). Internationalization and innovation performance of emerging market enterprises: the role of host-country institutional development. Journal of World Business, 51, 251-263.

Guba, E. G. (1990). The paradigm dialog. Newbury Park, CA: Sage.

Kuhn, T. S. (1970). The structure of scientific revolutions (2nd ed.). Chicago: University of Chicago Press.

Sarantakos, S. (1998). Social Research (2nd Ed). China: Macmillan Publishers.

Neuman, W. L. (2013). Social Research Methods, Qualitative and Quantitative Approaches, (7th Ed). USA: Pearson Higher Education.

Soejono, H., Abdurrahman, H. (2005). Metode Penelitian: Suatu Pemikiran dan Penerapan. Jakarta: Rineka Cipta.

Coviello, N. E., Mcauley, A. (1999). Internationalization and the small firm, A Review of Contemporary Empirical Research. Management International Review, 39, 223-237.

Westhead, P., Ucbasaran, D., Biks, M. (2004). Internationalization strategies selected by established rural and urban SMSs. Journal of Small Business and Entrepreneurship Development, 11, 8-22.

Hutchinson, K., Alexander, N., Quinn, B. (2005). The internationalization of small to medium-sized retail firms: towards a conceptual framework. Journal of Marketing Management, 21, 149-179. 